\title{
Overview of Drug Allergy: From Immunogenetic Basis to Practice
}

\section{Alergia a Fármacos: Da Imunogenética à Clínica}

Eunice DIAS DE CASTRO $\triangle^{1,2}$, Fabrícia CAROLINO1 ${ }^{1}$, Laura RIBEIRO ${ }^{3,4,5}$, Josefina R. CERNADAS ${ }^{1}$

Acta Med Port 2018 Oct;31(10):581-588 - https://doi.org/10.20344/amp.10092

\section{ABSTRACT}

Drug therapy is often a balance between the beneficial and harmful effects of drugs. Drug allergic reactions are adverse reactions mediated by immunological mechanisms and usually not related to the pharmacological actions of the drug. They can be classified based either on the clinical presentation or the underlying immunological mechanism. Although uncommon, drug allergic reactions are unpredictable and can be very severe, even life threatening. The aim of this review was to provide clinicians from different medical specialties with a working tool to improve management of their patients with suspected drug allergy. It was conducted as a nonsystematic review, and attempts to describe the complexity of drug allergy. The information included ranges from pathophysiology to the heterogeneous clinical presentation, with a special focus on the drugs most frequently involved, as well as a classification of reactions and risk factors. Despite all advances in this challenging and complex field of allergy and clinical immunology, drug allergy is not yet fully established and understood. An exceptional contribution was brought by pharmacogenomics, even though a specific pharmacogenetic association has only been defined for a very limited number of drugs. Further studies are needed to obtain clearer answers when managing each individual case of drug allergy.

Keywords: Drug Hypersensitivity/etiology; Drug Hypersensitivity/immunology; Pharmacogenetics; Drug-Related Side Effects and Adverse Reactions

\section{RESUMO}

A terapêutica farmacológica consiste, frequentemente, num equilíbrio entre os efeitos benéficos e prejudiciais dos fármacos. As reações alérgicas a fármacos são reações adversas mediadas por mecanismos imunológicos e não relacionadas com as ações farmacológicas do fármaco. Podem ser classificadas quer com base na apresentação clínica, quer no mecanismo imunológico subjacente. Embora pouco comuns, as reações alérgicas a fármacos são imprevisíveis, podendo ser graves e potencialmente fatais. O objetivo da presente revisão da literatura foi disponibilizar aos clínicos de diversas áreas médicas uma ferramenta de trabalho para uma melhor abordagem dos seus doentes com suspeita de alergia a fármacos. Foi conduzida de forma não sistemática e procura descrever a complexidade das reações alérgicas a fármacos, desde a fisiopatologia à heterogeneidade da apresentação clínica. Foi dado especial destaque aos fármacos mais frequentemente envolvidos, à classificação das reações e aos fatores de risco. Apesar de todos os avanços nesta área desafiante e complexa da alergologia e imunologia clínica, a alergia a fármacos não está ainda completamente compreendida e estabelecida. A farmacogenética trouxe um contributo excecional, embora apenas para um número muito limitado de fármacos esteja definida uma associação farmacogenética. São necessários estudos adicionais que permitam obter respostas mais diretas na abordagem de cada caso individual de alergia a fármacos.

Palavras-chave: Efeitos Colaterais e Reações Adversas Relacionados a Medicamentos; Farmacogenética; Hipersensibilidade a Medicamentos/etiologia; Hipersensibilidade a Medicamentos/imunologia

\section{INTRODUCTION}

Drug therapy is often a balance between the beneficial and harmful effects of drugs. Despite the intensive research in the field, adverse drug reactions (ADRs) remain a major problem. An ADR has been defined by the World Health Organization as any noxious, unintended and undesired effect of a drug occurring at doses normally used for prevention, diagnosis or treatment. ${ }^{1}$ It has been estimated that ADRs account for $3 \%$ to $6 \%$ of all hospital admissions and occur in $10 \%$ to $15 \%$ of hospitalized patients, contributing to morbidity and mortality. ${ }^{2,3} \mathrm{~A}$ widely used classification system divides ADRs in type $A$ (predictable, common, related to the pharmacological properties of the drug), and type $B$ (unpredictable, uncommon, unrelated to the pharmacological actions of the drug). The first type comprises approximately $80 \%$ of all ADRs and includes drug-induced toxicity,

side effects and drug interactions. ${ }^{4-7}$ Drug allergic reactions (DARs) are those mediated by immunological mechanisms and belong to type B. In practice, based on the clinical presentation alone, it is often difficult to differentiate between immune and non-immune mediated reactions. Therefore, the term drug hypersensitivity is applied when an immunological mechanism cannot be demonstrated in drug reactions that clinically look like allergic. Drug hypersensitivity reactions (DHRs) comprise 15\% of all ADR. DARs, although less common (estimated to represent a small percentage of all ADRs), can be very complex and potentially severe, even life-threatening. ${ }^{1,4}$

The study of DARs is challenging ${ }^{5}$ and is constantly updated as new drugs are developed and drug consumption patterns are changed. ${ }^{6}$

\footnotetext{
1. Allergy and Clinical Immunology Department. Centro Hospitalar São João. Porto. Portugal.

2. MedInUP-Center for Drug Discover and Innovative Medicines. Faculty of Medicine. University of Porto. Porto. Portugal.

3. Biomedicine Department. Faculty of Medicine. University of Porto. Porto. Portugal.

4. Public Health and Forensic Sciences, and Medical Education Department. Faculty of Medicine. University of Porto. Porto. Portugal.

5. I3S- Instituto de Investigação e Inovação em Saúde. University of Porto. Porto. Portugal.

$\square$ Autor correspondente: Eunice Dias de Castro.eunicediascastro@gmail.com

Recebido: 17 de dezembro de 2017 - Aceite: 09 de agosto de 2018| Copyright @ Ordem dos Médicos 2018
} 
The aim of this review of the current literature was to provide clinicians from different medical specialties with a working tool to improve management of their patients with suspected drug allergy (DA). It was conducted as a non-systematic review, and attempts to describe the complexity of DA. The information included ranges from pathophysiology to clinical presentation, with a special focus on the drugs most frequently involved, as well as classification of reactions and risk factors.

\section{1 - Classification}

A consensus classification is mandatory to guide and validate the diagnostic work-up. DARs can be classified based on the clinical presentation or the underlying immunological mechanism (Table 1).

Clinically, DARs are classified depending on the time elapsed between drug administration and the onset of symptoms: immediate (usually occurring up to one hour; could be between 1 to 6 hours: accelerated reactions) and non-immediate (at any time, after one hour and up to several days of drug administration). ${ }^{4}$

Any of the four immunologic mechanisms proposed by Gell and Coombs may underlie DARs, being the $\operatorname{lgE}$ and T-cell-mediated the most common. ${ }^{4,9}$ Type I, also known as immediate reactions (IRs), are mediated by drug-specific IgE antibodies. Type II (cytotoxic) and Type III (immune complex) are mediated by drug-specific IgG or IgM anti- bodies. Type IV are mediated primarily by $T$ cells $s^{4-6,9-12}$ and have been recently classified in 4 subtypes, according to cytokine patterns and the preferential activation of different immunocytes. ${ }^{9}$

\section{2 - Clinical Presentation}

2.1 - Immediate reactions (IRs): IRs present as isolated symptoms (urticaria, angioedema, conjunctivitis, rhinitis, bronchospasm) or as a severe reaction such as anaphylaxis. Urticaria/angioedema and anaphylaxis are the most common. The IgE-mediated allergy to $\beta$-Lactam $(\beta L)$ antibiotics is the paradigmatic example., ${ }^{4,13,14}$

2.2 - Non-immediate reactions (NIRs): The skin is the most frequently involved organ, with a wide range of clinical presentations. Maculopapular exanthema (MPE) and delayed urticaria are the most common.,4,10,13 Fixed drug eruption (FDE), acute generalized exanthematic pustulosis (AGEP), erythema multiforme (EM) and eczema are other presentations. $^{12}$

Both skin and other organs can be involved, as in drug rash with eosinophilia and systemic symptoms (DRESS)/ drug-induced hypersensitivity syndrome (DiHS), vasculitis and Stevens-Johnson syndrome (SJS)/ toxic epidermal necrolysis (TEN). $4 ., 6,10,13$.

Mild eruptions usually occur one to few days after the drug treatment is started, while most severe reactions often

Table 1 - Classification of drug allergies (adapted from ${ }^{4}$ )

\begin{tabular}{|c|c|c|c|c|c|}
\hline Type & $\begin{array}{l}\text { Type of immune } \\
\text { response }\end{array}$ & Pathophysiology & $\begin{array}{l}\text { Timing of } \\
\text { reaction }\end{array}$ & Clinical symptoms & $\begin{array}{l}\text { Typical chronology } \\
\text { of the reaction }\end{array}$ \\
\hline I & $\lg E$ & $\begin{array}{l}\text { Mast cell and basophil } \\
\text { degranulation }\end{array}$ & Immediate & $\begin{array}{c}\text { Anaphylaxis } \\
\text { Urticaria/Angioedema } \\
\text { Bronchospasm } \\
\text { Rhinitis }\end{array}$ & $\begin{array}{l}\text { Immediate, usually up to one hour, } \\
\text { but could occur between } 1 \mathrm{~h} \text { to } 6 \mathrm{~h} \\
\text { after the last drug intake }\end{array}$ \\
\hline II & IgG and complement & $\begin{array}{l}\lg G \text { and complement- } \\
\text { dependent cytotoxicity }\end{array}$ & \multirow{6}{*}{ Non-immediate } & Cytopenia & $\begin{array}{c}5-15 \text { days after the start of } \\
\text { the eliciting drug }\end{array}$ \\
\hline III & $\begin{array}{l}\operatorname{lgM} \text { or IgG and } \\
\text { complement or FcR }\end{array}$ & $\begin{array}{c}\text { Deposition of } \\
\text { immune complexes }\end{array}$ & & $\begin{array}{l}\text { Serum sickness } \\
\text { Urticaria } \\
\text { Vasculitis }\end{array}$ & $\begin{array}{l}7-8 \text { days after the start of the } \\
\text { eliciting drug for serum sickness/ } \\
\text { urticaria; } \\
7-21 \text { days for vasculitis }\end{array}$ \\
\hline IV a & Th1 (IFN-gamma) & Monocytic inflammation & & Eczema & $\begin{array}{c}1-21 \text { days after the start of } \\
\text { the eliciting drug }\end{array}$ \\
\hline IV b & Th2 (IL-4 and IL-5) & $\begin{array}{l}\text { Eosinophilic } \\
\text { inflammation }\end{array}$ & & $\begin{array}{c}\text { MPE } \\
\text { DRESS/ DiHS }\end{array}$ & $\begin{array}{c}1 \text { to several days after the start of } \\
\text { the eliciting drug for MPE; } \\
2-6 \text { weeks for DRESS/DiHS }\end{array}$ \\
\hline IV c & $\begin{array}{c}\text { Cytotoxic T cells } \\
\text { (perforin, granzyme B, } \\
\text { FasL, granulysin) }\end{array}$ & $\begin{array}{l}\text { Keratinocytic death } \\
\text { mediated by } \\
\text { CD4 or CD8 }\end{array}$ & & $\begin{array}{l}\text { MPE } \\
\text { FDE } \\
\text { SJS/TEN }\end{array}$ & $\begin{array}{c}1-2 \text { days after the start of the } \\
\text { eliciting drug for FDE; } \\
4-28 \text { days for SJS/TEN }\end{array}$ \\
\hline IV d & T cells (IL-8/CXCL8) & $\begin{array}{l}\text { Neutrophilic } \\
\text { Inflammation }\end{array}$ & & AGEP & $\begin{array}{l}1-2 \text { days after the start of the } \\
\text { elicitting drug, but can be longer }\end{array}$ \\
\hline
\end{tabular}

IgE: Immunoglobulin E; IgM: Immunoglobulin M; IgG: Immunoglobulin G; Th1: T helper1; Th2: T helper 2; IFN gamma: Interferon gamma; IL4: Interleukin 4; IL5: Interleukin 5; IL8: Interleukin 8; CXCL8: Chemokine motif ligand 8; MPE: Maculopapular exanthema; DRESS: Drug rash with eosinophilia and systemic symptoms; DiHS: Drug-induced hypersensitivity syndrome; FDE: Fixed drug eruption; SJS: Stevens-Johnson syndrome; TEN: Toxic epidermal necrolysis; AGEP: Acute generalized exanthematic pustulosis. 
begin later on (SJS/TEN: 4 - 21 days; DRESS/DiHS: 2 - 6 weeks). ${ }^{4}$

DRESS is an unusual DAR characterized by the presence of morbilliform rash, atypical lymphocytosis, eosinophilia, fever and other organ involvement, usually liver. ${ }^{12,15} \mathrm{~A}$ minimum criterion of rash, fever, hepatitis and lymphocytosis has been proposed for DiHS. ${ }^{16}$

SJS and TEN, the most severe type of reactions affecting the skin, are characterized by extensive epidermal detachment and mucous membrane erosion, including oral, conjunctival and anal. ${ }^{10,12}$ Although uncommon (estimated prevalence: 5 - 6 cases and 1 - 2 cases per million patients for SJS and TEN, respectively), ${ }^{17}$ the morbidity and mortality is high $\left(5 \%-10 \%\right.$ mortality for SJS ${ }^{16,17}$ and $30 \%-50 \%$ for TEN). ${ }^{12,16-18}$ Several authors support that SJS and TEN are a single disease with common causes and physiopathology, but different spectrums of severity according to the extension of epidermal detachment $(<10 \%$ : SJS; $10 \%-30 \%$ : SJS - TEN overlapping; > 30\% : TEN)..$^{10,12,16-18}$ Drugs causing SJS/TEN overlap with those causing DRESS/DiHS: aromatic amine anticonvulsants, sulfonamides antibiotics, nonsteroidal anti-inflammatory drug (NSAIDs) and antiretroviral agents. Allopurinol and lamotrigine were also associated with SJS/TEN. ${ }^{10,12,16,17}$

EM is characterized by the presence of target-shaped lesions and, although less severe, can be an early presentation of SJS/TEN. Any of these reactions contraindicate the re-administration of the culprit drug. ${ }^{12}$

\section{3 - Pathogenesis and Physiopathology}

3.1 - Chemical basis: For a drug to become an antigen able to elicit an immune response, two main mechanisms have been proposed: 1 . The drug, a chemically reactive small-molecule, must bind irreversibly to a protein, generating antigens (hapten concept); 2 . The drug, chemically inert, needs to be converted into reactive metabolites before binding irreversibly to proteins (pro-hapten concept). ${ }^{4-5,19-22}$

For T-cell mediated reactions, the role of a carrier-protein/hapten has not been fully defined as it has been for IgE-mediated reactions. ${ }^{4,19}$

An alternative hypothesis is that some drugs might also originate a direct reversible interaction with the T-cell receptors or HLA-molecules, activating T cells by pharmacological interaction ( $p-i$ concept). ${ }^{9}$ According to this hypothesis, the drug eliciting an immunological response is not dependent on its structural features nor metabolism. Chemically inert drugs are able to directly activate T-cell receptors. ${ }^{4-5,11,20,21}$

Cross-reactivity between drugs is an immunological reaction that occurs on exposure to different drugs with a similar molecular structure. This can happen even without any previous exposure to the cross-reacting drug, allowing to predict, to some extent, the risk of reactivity to chemically related drugs. ${ }^{11}$

3.2 - Immunopathological mechanisms: It has been proposed that drug-protein conjugates might be processed and presented by antigen-presenting cells to naive T cells, after drug intake, inducing tolerance or effector responses. ${ }^{24}$ In the last case, the immune system develops either immediate T-helper2 (Th2)- type responses, mediated by specific IgE antibodies, or non-immediate Th1-type responses, mainly mediated by specific T cells..$^{5,10}$ Alternatively, T cells could be directly stimulated by the drug. ${ }^{9}$

3.2.1 - Immediate reactions: IRs develop as a result of IgE production. At an initial sensitization phase, B-cells proliferate and differentiate into plasma cells, in the presence of specific Th2-cells. Drug-specific IgE are then produced and bind to the high-affinity FcRI receptors on the surface of mast cells and basophils. On subsequent drug exposure, the drug antigen cross-links IgE on the surface of mast cells, activating them and inducing the release of preformed mediators (e.g., histamine, tryptase, TNF- $\alpha$ ) and the production of new ones (e.g., leukotrienes, prostaglandins, cytokines). The sensitization phase is usually asymptomatic and may have occurred during an earlier drug treatment. ${ }^{4,5}$

3.2.2 - Non-immediate reactions: The majority are mediated by T lymphocytes. ${ }^{4}$ Most of the information available relates to the specific effector immune response mediated by $T$ cells. Little is known about the initial steps mediated by the innate immune system, mainly by dendritic cells. ${ }^{10,23}$ It has been proposed that these cells can process the drug antigen as a first step to stimulate naive T cells. ${ }^{4}$ The antigen is internalized and transported to the regional lymph nodes, where it is presented to naive T cells. Alternatively, it may stimulate directly pathogen-specific $T$ cells, without priming by dendritic cells. Antigen-specific $T$ cells migrate to target organs and on re-exposure to the drug, are activated to secrete cytokines.

Other immune cells are involved in NIRs, fitting into the four subtypes of Type IV reactions ${ }^{9}$ : IVa). Th1 cells produce interferon- $y$-activated macrophages, typically in eczema; IVb). Th2 cytokines induce the production of antibodies by $B$ cells and the eosinophil responses, mainly in MPE and DRESS; IVc). CD4+ and CD8+ T cells produce cytotoxic mediators leading to keratinocyte apoptosis in MPE and massive apoptosis in SJS/TEN; IVd). neutrophil recruitment and T-cell-induced activation by the production of a chemokine, CXCL8, mainly in AGEP.

The histopathology findings in SJS/TEN show detachment of a large portion of the epidermis. ${ }^{12}$ Previously, FasFasL interaction and perforin-granzyme $B$ were the pathways reported as basic effectors. ${ }^{12,16}$ More recently, granulysin was described as a key effector responsible for the death of keratinocytes. ${ }^{16,18,24}$ Granulysin concentrations in blister fluid seem to correlate with the severity of SJS/TEN ${ }^{24}$ and high granulysin serum levels may be a useful early diagnostic biomarker. ${ }^{18}$

In a minority of NIRs other immune mechanisms may be involved. Type II reactions concern IgG-mediated cytotoxicity directed to membranes of erythrocytes, leukocytes and platelets. Drugs typically involved are methyldopa (hemolytic anemia), aminopyrine (leukopenia), and heparin (thrombocytopenia). Such reactions may occur only as long as the drug is present in soluble form. Type III reactions 
involve the formation of immune complexes (IC), a common event in a normal immune response, usually asymptomatic. On rare occasions, IC bind to endothelial cells and lead to IC deposition with complement activation in small blood vessels, resulting in serum sickness syndrome (SSS), drug-induced lupus erythematosus or vasculitis. ${ }^{5}$

3.3 - Pharmacogenetics: The discovery of strong associations between certain severe reactions, mostly NIRs, and HLA-B alleles has allowed a great progress in DA. ${ }^{4,16-}$ 18,20,21 The association of HLA alleles with SJS/TEN has been reported, for the first time, more than 25 years ago..$^{25}$ Since then, specific HLA alleles have been found to be associated with this disease. ${ }^{17} \mathrm{~A}$ strong association between carbamazepine (CBZ)-induced SJS/TEN and HLA-B*1502 has been described in a Chinese population, where this allele was present in all patients suffering from CBZ-induced SJS. Subsequently this association was also found in Indian and Thai, but not in Japanese nor in European patients..$^{16,21}$ This association seems to be phenotype-specific (SJS/TEN) ${ }^{4}$ and is stronger than any other described so far. ${ }^{17,21}$

In northern Europeans, the presence of HLA-A*3101 has been associated with a wide spectrum of CBZ-induced reactions (MPE, DRESS/DiHS, SJS/TEN) ${ }^{26}$

Other important association include HLA-B*5801 and SJS/TEN or DRESS/DiHS with allopurinol, in Asian $^{16}$ and European populations. ${ }^{16,27}$

Finally, the carriage of HLA-B*5701 has been strongly associated with flucloxacillin-induced liver injury ${ }^{16,21}$ and with abacavir hypersensitivity syndrome, a severe multi-organic reaction. . $16,21,28,29$ This association was higher among Caucasians, where the allele was present in $94.4 \%$ cases (positive predictive value $\geq 70 \%$; negative predictive value: 95\% - 98\%). ${ }^{29}$ International HIV treatment guidelines recommend the HLA-B ${ }^{*} 5701$ screening prior to the abacavir treatment. ${ }^{30}$

Recent pharmacogenomic studies evolving from a candidate-gene approach to the genome-wide association study (GWAS) brought great advances in the discovery of genes associated with inter-individual differences in drug response (mainly genes predisposing to ADRs but also genes responsible for drug efficacy). The HLA system has been a major focus for type $B$ reactions, particularly the more severe immune reactions. ${ }^{16,17} \mathrm{~A}$ number of polymorphisms located on chromosome 6 have been found in association with SJS/TEN induced by allopurino ${ }^{31}$ and abacavir. ${ }^{32}$ In IRs, some polymorphisms in cytokine genes have been weakly associated with $\beta L$-induced anaphylaxis. ${ }^{33-35}$

This greater knowledge has made some DARs quite predictable. ${ }^{16,20,21}$

3.4 - Risk factors: There are few identified factors influencing the risk of sensitization and the severity of DARs. These are the chemical structure of the molecule, the nature of drug exposure (dose, route, frequency and duration), the presence of co-factors (e.g. stress, infections), genetic predisposition, immune status and female gender. ${ }^{1,5,20}$ In

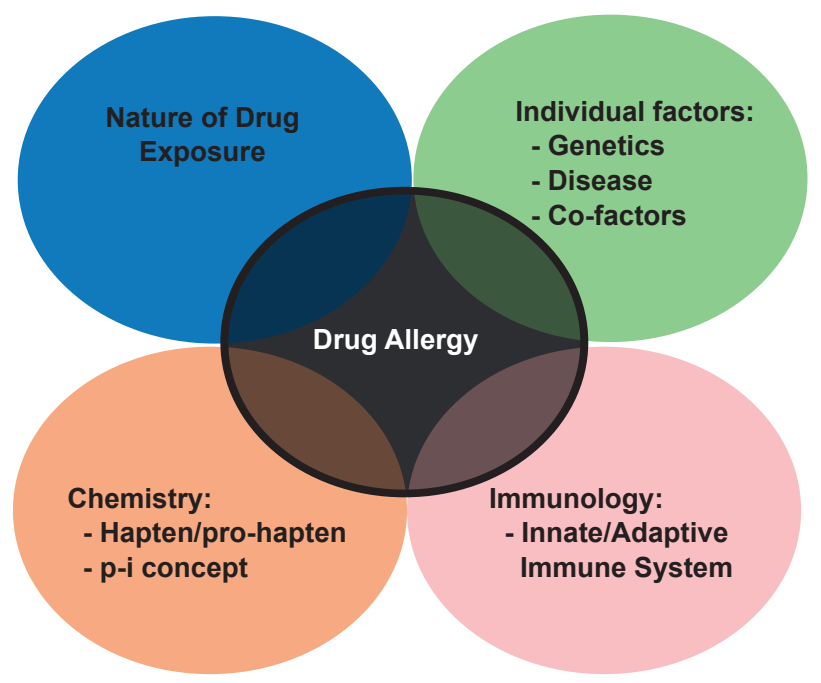

Figure 1 - Drug Allergy: a balance between drug factors and patient biology (adapted from ${ }^{21}$ )

p-i concept: Pharmacological interaction with immune receptors.

the balance between drug and individual factors (Fig. 1), a disturbed immunologic status associated with the development of recurrent infections, decreases the threshold to induce a response. Moreover, the HLA genotype can dictate the way in which a drug can cause allergy. ${ }^{22}$

Anaphylaxis has been associated with certain drugs (NSAIDs, radiocontrast media, antibiotics, opioids, perioperative drugs) in patients with mast cell disorders. However, data are scarce and evidence for an association is limited. Nevertheless, mastocytosis should be ruled out in cases of severe anaphylaxis. ${ }^{36}$

3.4.1 - The role of viruses: Viral infections are the main cause of skin reactions that can mimic DARs if the drug, usually an antibiotic, is taken simultaneously. Viruses can also interact with drugs and immune system, leading to allergic reactions such as the mild ampicillin exanthema linked to the Epstein-Barr virus (EBV) infection or DRESS/ DiHS. ${ }^{4,10,20-22,37,38}$ DRESS/DiHS is the best studied DAR associated with viral infection and has been linked to the reactivation of human herpes virus (HHV)-6. EBV, cytomegalovirus and other HHV, even days or weeks after the discontinuation of the drug. ${ }^{4,10,16,22,38,39}$

The interaction with the immune system can occur at several points: drug metabolism; drug presentation to $T$ cells, by dendritic cells; and effector response (cytokine and chemokine production). ${ }^{10}$

\section{4 - Allergic reactions to specific drugs \\ 4.1 - Antibiotics}

4.1.1 - $\beta$-Lactams: $\beta$ Ls are still the most frequent cause of DARs. Benzylpenicillin was the first $\beta L$ implicated, but amoxicillin has progressively become the most common culprit. A wide range of manifestations can occur, reflecting different underlying immunological mechanisms. They can induce IRs, mediated by IgE (usually urticaria/angioedema and anaphylaxis) and also NIRs (mainly MPE). Severe NIRs (AGEP, SJS/TEN, DRESS) can also occur. ${ }^{6,13}$ 
$\beta$ Ls clearly induce immunological reactions due to hapten-carrier formation which occur through the nucleophilic opening of the $\beta \mathrm{L}$ ring and the generation of reactive intermediates. ${ }^{6,13,22}$ Recent studies have pointed out the relevance of the three-dimensional shape of the $\beta \mathrm{L}$, as well as its inherent chemical reactivity, in determining the selectivity of the covalent binding. ${ }^{20}$ The role of side chains that distinguish different penicillin compounds as relevant allergenic determinants is also widely accepted, particularly in IRs to aminopenicillins and cephalosporins. Thus, cephalosporins with a similar side-chain should be avoided in patients with IgE-mediated reactions to penicillin. ${ }^{13,40}$ Moreover, in cases of IRs to penicillin, skin testing with alternative drugs (cephalosporins, carbapenems, aztreonam) is recommended prior to its administration. If negative, the drug should be given by increasing doses in an appropriate setting. ${ }^{13}$

In NIRs to aminopenicillins, both core structure and the whole molecule (core structure plus the amino-benzyl group of the side-chain) are recognized by $\mathrm{T}$ cells, although the latter plays a predominant role. ${ }^{13}$ Despite the fact that cross-reactivity between penicillins, cephalosporins and carbapenems for T-cell reactions is very rare, it also demands investigation. ${ }^{13,41}$

4.1.2 - Sulfonamides: Sulfonamides are defined as drugs with a SO2-NH2 moiety. Sulfonamide antibiotics also contain an aromatic amine (N4 position) and a substituted ring (N1 position). ${ }^{40}$ After $\beta$ Ls, sulfonamide antibiotics (namely sulfamethoxazole-SMX) are the most common cause of DARs. ${ }^{40,42}$ SMX usually cause cutaneous NIRs and rarely IgE-mediated reactions ${ }^{12,22,40}$ through the direct activation of $\mathrm{T}$ cells by covalent binding or acting as pro-hapten, respectively, as SMX is a chemically inert

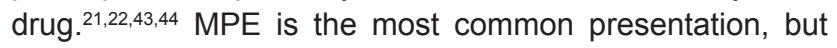
SJS/TEN were also described. ${ }^{12,22,40,42}$

About $40-80 \%$ of HIV patients treated with trimethoprim (TMP)-SMX develop a generalized MPE, usually accompanied by fever, while the incidence of skin rashes to TMPSMX in healthy subjects is only $3 \%$ to $5 \%$. The increased risk in HIV patients is probably related to immunologic and metabolic factors and to the frequent exposure to TMPSMX.42

The N4 aromatic amine is critical for the development of NIRs to sulfonamide antibiotics and the N1 substituted ring appears to be important for IgE-mediated reactions. As non-antibiotic sulfonamides lack these structural components, cross-reactivity with sulfonamide antibiotics is not expected. ${ }^{12,40,42}$ Conversely, all sulfonamide antibiotics should be considered to be cross-reactive. ${ }^{11}$

4.1.3 - Fluoroquinolones: This widely used class of broad-spectrum antibiotics can induce reactions mediated by IgE (hapten-carrier formation) and $T$ cells ( $p-i$ mechanism).$^{6,45-47}$ that are estimated to occur in $2 \%$ to $3 \%$ of the treated patients. ${ }^{45} \mathrm{IgE}$-mediated reactions are more common and usually severe, with anaphylaxis as the most frequent presentation. Urticaria/angioedema can also occur. NIRs are less frequent and include MPE, FDE, vasculitis, AGEP and SJS/TEN. ${ }^{6,45-47}$ Moxifloxacin induces more se- vere reactions ${ }^{6}$ and is the main culprit, followed by ciprofloxacin and levofloxacin.6,46 As cross-reactivity between these antibiotics is common avoidance of all quinolones is advisable. ${ }^{12,48}$

\section{2 - Nonsteroidal anti-inflammatory drugs: NSAIDs} are responsible for $21 \%$ to $25 \%$ of reported ADRs, including immunological and non-immunological reactions. Depending on the clinical presentation and the presumable underlying mechanism, hypersensitivity to NSAIDs is classified in 2 groups and 5 subgroups (Table 2). ${ }^{49}$ In the first group ( $\geq 75 \%$ of cases), ${ }^{6}$ the putative mechanism is the inhibition of ciclooxigenase-1, hence hypersensitivity to multiple NSAIDs is observed regardless of their chemical structure and/or anti-inflammatory potency. ${ }^{49}$

The second group involves the selective reactions, probably with an underlying immunological mechanism: a) IgE-mediated is the proposed mechanism in cases of urticaria, angioedema and anaphylaxis induced by a single NSAID or a group of chemically related drugs. ${ }^{49,50}$ Pyrazolones, paracetamol, ibuprofen, diclofenac and naproxen are the most common. ${ }^{49}$ The last three compounds have a heteroaryl acetic group, presumably carrying a higher risk of anaphylaxis (OR 19.7); ;1 b) NIRs, probably T-cell mediated, were also reported to be induced by a single NSAID or a group of chemically related drugs. ${ }^{49-51}$ Cutaneous reactions, particularly MPE are the most frequent reaction. NSAIDs are the main cause of FDE and can also induce SJS/TEN (particularly oxicams). ${ }^{49}$

Diagnostic and management guidelines for children and adolescents with NSAIDs hypersensitivity, including a modified classification, were recently published considering specific clinical and epidemiological features. ${ }^{52}$

4.3 - Neuromuscular blocking agents (NMBAs): Immediate HRs during the perioperative period have been increasingly reported. ${ }^{53}$ Most are mediated by $\operatorname{lgE}$ and less frequently related to direct stimulation of histamine release. ${ }^{53-55}$

$\mathrm{IgE}$ mechanism causes perioperative anaphylaxis (estimated incidence of $1: 10000$ to $1: 20000$ ) and any drug administered in this period can potentially induce it. ${ }^{53}$ Different populations exhibit different patterns of sensitization. ${ }^{7}$ NMBAs are the most common cause in Europe (50\% - 70\%), followed by antibiotics and latex. While latex is becoming a less common culprit, chlorhexidine is gaining importance and sugammadex is an emerging cause. ${ }^{54}$

Suxamethonium is the most frequent reported culprit, with a recent increment of rocuronium, vecuronium and pancuronium. ${ }^{53,56,57}$ Sensitization to NMBAs seems to demand the presence of a substituted ammonium ion. In many cases, the reaction may occur at the first exposure, since a prior sensitization to another compound with a substituted ammonium ion (e.g. pholcodine) may have occurred. $5,54,55,57$ Investigation of cross-reactivity between NMBAs is mandatory in diagnostic work-up. ${ }^{58-62}$ 
A new mast cell receptor MRGPRX2 (human Mas-related G-protein-coupled receptor member X2) was discovered and related with reactions to NMBAs not IgE-mediated, ${ }^{54-55}$ which could explain the cases of perioperative anaphylaxis with negative skin testing (mast cell direct activation through this receptor). ${ }^{54}$

4.4 - Radiocontrast media: In the past the ionic high-osmolar RCM induced a high incidence of IRs due to the nonspecific release of vasoactive mediators. ${ }^{6}$ Despite the introduction of nonionic (NI) low-osmolar RCM, hypersensitivity reactions (HSRs) are still a matter of concern. A recent European multicenter study suggests that at least $50 \%$ of the HRs to NI-RCM are caused by an immunological mechanism. Cross-reactivity was frequent among NI-RCM with a very similar chemical structure. ${ }^{58}$ It is estimated that $\mathrm{NI}-\mathrm{RCM}$ can cause IRs and NIRs in about $1 \%-3 \%$ of applications. ${ }^{59}$ IRs are mainly anaphylaxis, whereas NIRs predominantly manifest as mild skin eruptions occurring hours to days after RCM administration. ${ }^{58-62}$

4.5 - Biological modifiers: The biologic agents have been recently developed and are increasingly used. They comprise proteins such as cytokines and monoclonal antibodies (mAbs) ${ }^{6,40}$ that differ from other drugs as they have high molecular-weight with a great immunogenic potential. ${ }^{40}$ Three major groups of mAbs are in use: chimeric (-ximab), humanized (-zumab) and human antibodies (-mumab). They can induce reactions through different immunological mechanisms. ${ }^{63,64}$ Clinical phenotypes include IRs (type I; infusion-related reactions, cytokine release, mixed reactions), type III and type IV delayed reactions. ${ }^{64}$

IgE-mediated reactions to basiliximab, infliximab and rituximab have been reported. ${ }^{6,7,42} \mathrm{IgE}$ antibodies to cetuximab specifically for alpha-1,3-galactose have been found in the majority of anaphylactic reactions. ${ }^{7,65}$ Rare delayed anaphylaxis has been reported after exposures to omalizumab, trastuzumab, daclizumab, infliximab and basiliximab. ${ }^{12}$

Some patients present $\lg G$ antibodies to biologics that may block the effect of the drug or be involved in the development of HSRs. ${ }^{64}$

NIRS are rare but have been described, after rituximab (vasculitis, SSS) ${ }^{7}$ and infliximab (SSS, SJS, DiHS). ${ }^{40}$

Desensitization allows a safe reintroduction of first-line biologic agent. ${ }^{64,66}$

4.6 - Antineoplastic agents: HSRs to antineoplastic agents are an increasing problem. ${ }^{67,68}$ Any cytostatic can potentially expose the patient to the risk of an immune reaction. They can elicit either immediate (urticaria, bronchospasm, dyspnea, thoracic/abdominal pain, fever, anaphylaxis) or NIRs (macular/MPE, vasculitis). The severity of reactions ranges from mild symptoms to life-threatening anaphylaxis. ${ }^{67}$

HSRs are more common with platinum compounds (cisplatin, carboplatin, oxaliplatin), epipodophyllotoxins (teniposide, etoposide), asparaginase, taxanes (paclitaxel) and procarbazine. Doxorubicin and 6-mercaptopurine are rare culprits. HSR to carboplatin and oxaliplatin are particularly frequent (incidence: $12 \%-17 \%$ ), with more than $50 \%$ of the reactive patients developing moderate to severe

Table 2 - Classification of Hypersensitivity Reactions Induced by NSAIDs (adapted from ${ }^{55}$ )

\begin{tabular}{|c|c|c|c|c|c|c|}
\hline Type of reaction & $\begin{array}{c}\text { Clinical } \\
\text { manifestations }\end{array}$ & $\begin{array}{l}\text { Timing of } \\
\text { reaction }\end{array}$ & $\begin{array}{l}\text { Underlying } \\
\text { disease }\end{array}$ & $\begin{array}{l}\text { Cross- } \\
\text { reactivity }\end{array}$ & $\begin{array}{l}\text { Presumable } \\
\text { mechanism }\end{array}$ & \\
\hline $\begin{array}{l}\text { NSAID-exacerbated } \\
\text { respiratory disease } \\
\text { (NERD) }\end{array}$ & $\begin{array}{l}\text { Bronchospasm } \\
\text { Nasal symptoms }\end{array}$ & & $\begin{array}{c}\text { Asthma } \\
\text { rhinosinusitis }\end{array}$ & & & \\
\hline $\begin{array}{c}\text { NSAID-exacerbated } \\
\text { cutaneous disease } \\
\text { (NECD) }\end{array}$ & Urticaria and/or & $\begin{array}{l}\text { Acute (usually } \\
\text { immediate to } \\
\text { several hours }\end{array}$ & Chronic urticaria & $\begin{array}{l}\text { Cross- } \\
\text { reactive }\end{array}$ & Non-allergic & \\
\hline $\begin{array}{c}\text { NSAID-induced urticaria/ } \\
\text { angioedema } \\
\text { (NIUA) }\end{array}$ & angıoedema & אלום & & & & $\begin{array}{l}\text { Unknown } \\
\text { (probably COX-1 } \\
\text { inhibition) }\end{array}$ \\
\hline $\begin{array}{l}\text { Single NSAID-induced } \\
\text { urticaria/angioedema or } \\
\text { anaphylaxis } \\
\text { (SNIUAA) }\end{array}$ & $\begin{array}{l}\text { Urticaria and/ } \\
\text { or angioedema/ } \\
\text { anaphylaxis }\end{array}$ & & $\begin{array}{l}\text { No underlying } \\
\text { chronic disease }\end{array}$ & & & IgE-mediated \\
\hline $\begin{array}{l}\text { Single NSAID-induced } \\
\text { delayed reactions } \\
\text { (SNIDR) }\end{array}$ & $\begin{array}{c}\text { Various symptoms and } \\
\text { organs involved (eg. } \\
\text { MPE, FDE, SJS/TEN, } \\
\text { nephritis) }\end{array}$ & $\begin{array}{l}\text { Delayed onset } \\
\text { (usually }>24 \mathrm{~h} \\
\text { after exposure) }\end{array}$ & & & & $\mathrm{T}$ cell-mediated \\
\hline
\end{tabular}

NSAID: Nonsteroidal anti-inflammatory drug; MPE: Maculopapular exanthema; FDE: Fixed drug eruption; SJS: Stevens-Johnson syndrome; TEN: Toxic epidermal necrolysis; COX-1: Ciclooxigenase 1; IgE: Immunoglobulin E. 
symptoms. ${ }^{69}$

Most reactions occur during the treatment (platinum derivatives and taxanes), although some appear hours after. Reactions to taxanes usually manifest during the first few minutes of the first or second infusion, whereas acute reactions to platinum agents usually occur after several cycles. ${ }^{65,68,70-72}$

Since these drugs are usually the first line therapy, patients can be desensitized ${ }^{71}$ when no equally effective alternative drugs are available. The desensitization should follow the general considerations for these procedures published in a consensus paper for IRs ${ }^{73}$ and NIRs. ${ }^{74}$

\section{CONCLUSION}

This exhaustive review, although the limitation of being non-systematic, pointed out that despite all advances, drug allergy is not yet fully established and understood. An exceptional contribution was brought by pharmacogenomics, even though a specific association has only been defined for a very limited number of drugs. Further investigation is needed to obtain clearer answers when managing each individual case of DA. The development of new biomarkers and a 'tailored-made' medicine is probably the future.

As knowledge in this field moves forward, new updates will be required.

\section{CONFLICTS OF INTEREST}

The authors declare they do not have any conflicts of interest and that they did not receive any financial support.

\section{0:59:325-32}

19. Pichler WJ, Beeler A, Keller M, Lerch M, Posadas S, Schmid D, et al. Pharmacological interaction of drugs with immune receptors: the $p-i$ concept. Allergol Int. 2006;55:17-25.

20. Pichler WJ, Naisbitt DJ, Park BK. Immune pathomechanism of drug hypersensitivity reactions. J Allergy Clin Immunol. 2011;127:S74-81.

21. Pirmohamed M, Ostrov DA, Park BK. New genetics finding lead the way to a better understanding of fundamental mechanisms of drug hypersensitivity. J Allergy Clin Immunol. 2015;136:236-44.

22. Faulkner L, Meng X, Park BK, Naisbitt DJ. The importance of haptenprotein complex formation in the development of drug allergy. In: Wolters Kluwer Health|Lippincott Williams \& Wilkins; 2014: Volume 14 - Number 4.

23. Lutz MB, Schuler G. Immature, semi-immature and fully mature dendritic cells: which signals induce tolerance or immunity? Trends Immunol. 2002;23:445-9.

24. Chung WH, Hung SI, Yang JY, Su SC, Huang SP, Wei CY, et al. Granulysin is a key mediator for disseminated keratinocyte death in Stevens-Johnson syndrome and toxic epidermal necrolysis. Nat Med. 2008;14:1343-50.

25. Roujeau JC, Huynh TN, Bracq C, Guillaume JC, Revuz J, Touraine R. Genetic susceptibility to toxic epidermal necrolysis. Arch Dermatol. 1987;123:1171-73

26. McCormack M, Alfirevic A, Bourgeois S, Farrell JJ, Kasperaviciute $D$, Carrington $M$, et al. HLA-A*3101 and carbamazepine induced hypersensitivity reactions in Europeans. N Engl J Med. 2011;364:113443.

27. Lonjou C, Borot N, Sekula P, Ledger N, Thomas L, Halevy S, et al. A European study of HLA-B in Stevens- Johnson syndrome and toxic epidermal necrolysis related to five high-risk drugs. Pharmacogenet Genom. 2008;18:99-107.

28. Mallal S, Phillips E, Carosi G, Molina JM, Workman C, Tomazic J, et al HLA-B*5701 screening for hypersensitivity to abacavir. N Engl J Med. 2008;358:568-79.

29. Davis CM, Shearer WT. Diagnosis and management of HIV drug hypersensitivity. J Allergy Clin Immunol. 2008;121:826-32.

30. Chaponda M, Pirmohamed M. Hypersensitivity reactions to HIV therapy. Br J Clin Pharmacol. 2011;71: 659-71.

31. Tohkin M, Kaniwa N, Saito Y, Sugiyama E, Kurose K, Nishikawa J, et al. A whole-genome association study of major determinants for allopurinolrelated Stevens-Johnson syndrome and toxic epidermal necrolysis in Japanese patients. Pharmacogenom J. 2013;13:60-6.

32. Colombo S, Rauch A, Rotger M, Fellay J, Martinez R, Fux C, et al The HCP5 single-nucleotide polymorphism: a simple screening tool for prediction of hypersensitivity reaction to abacavir. J Infect Dis. 2008;198:864-7

33. Guglielmi L, Fontaine C, Gougat C, Avinens O, Eliaou JF, Guglielmi P, et al. IL-10 promoter and IL4-Ralpha gene SNPs are associated with immediate beta-lactam allergy in atopic women. Allergy. 2006;61:9217.

34. Barbaud A, Waton J, Herbeth B, Bursztejn AC, Bollaert M, Schmutz 
$\mathrm{JL}$, et al. Comparison of cytokine gene polymorphism in drug-induced maculopapular eruption, urticaria and drug reaction with eosinophilia and systemic symptoms (DRESS). J Eur Acad Dermatol Venereol. 2014;28:491-9.

35. Oussalah A, Mayorga C, Blanca M, Barbaud A, Nakonechna A Cernadas J, et al. Genetic variants associated with drugs-induced immediate hypersensitivity reactions: a PRISMA-compliant systematic review. Allergy. 2016;71:443-62.

36. Bonaddona P, Pagani M, Aberer W, Biló MB, Brockow K, Oude Elberink $\mathrm{H}$, et al. Drug hypersensitivity in clonal mast cell disorders: ENDA EAACI position paper. Allergy. 2015;70:755-63.

37. Caubet JC, Kaiser L, Lemaitre B, Fellay B, Gervaix A, Eigenmann PA The role of penicillin in benign skin rashes in childhood: a prospective study based on drug rechallenge. J Allergy Clin Immunol. 2011;127:21822.

38. Camous X, Calbo S, Picard D, Musette P. Drug reaction with eosinophilia and systemic symptoms: an update on pathogenesis. Curr Opin Immunol. 2012;24:730-5

39. Cho YT, Yang CW, Chu CY. Drug reactions with eosinophilia and systemic symptoms (DRESS): An interplay among drugs, viruses, and immune system. Int J Mol Sci. 2017;18:1243.

40. Khan DA, Solensky A. Drug allergy. J Allergy Clin Immunol. 2010;125:S126-37.

41. Dias de Castro E, Leblanc A, Sarmento A, Cernadas JR. An unusual case of delayed-type hypersensitivity to ceftriaxone and meropenem. Eur Ann Allergy Clin Immunol. 2015;47:225-7.

42. Dibbern DA, Montanaro A. Allergies to sulfonamide antibiotics and sulfur-containing drugs. Ann Allergy Asthma Immunol. 2008;100:91-100.

43. Sanderson JP, Naisbitt DJ. Park K. Role of bioactivation in drug-induced hypersensitivity reactions. AAPS J 2006;8:E55-64.

44. Schnyder, Naisbitt DJ, Pichler WJ. Recognition of SMX and its reactives metabolites by drug-specific CD4+ Tcells from allergic individuals. J Immunnol. 2004;164:6647-54.

45. Schmid DA, Depta JP, Pichler WJ. T cell-mediated hypersensitivity to quinolones: mechanisms and cross-reactivity. Clin Exp Allergy. 2006;36:56-9.

46. Blanca-López N, Ariza A, Doña I, Mayorga C, Montañez MI, GarciaCampos J, et al. Hypersensitivity reactions to fluoroquinolones: analysis of the factors involved. Clin Exp Allergy. 2013;43:560-67.

47. Schmid DA, Pichler WJ. Hypersensitivity reactions to quinolones. Curr Pharm Des. 2006;12:3316-26.

48. Manfredi M, Severino M, Testi S, Nacchia D, Ermini G, Pichler WJ. Detection of specific IgE to quinolones: mechanisms and crossreactivity. J Allergy Clin Immunol. 2004;113:155-60.

49. Kowalski ML, Asero R, Bavbek S, Blanca M, Blanca-Lopez N, Bochenek $\mathrm{G}$, et al. Classification and practical approach to the diagnosis and management of hypersensitivity to nonsteroidal anti-inflammatory drugs. Allergy. 2013;68:1219-32.

50. Ortega N, Doña I, Moreno E, Audicana MT, Barasona MJ, BergesGimeno MP, et al. Practical guidelines for diagnosing hypersensitivity reactions to nonsteroidal anti-inflammatory drugs. J Investig Allergol Clin Immunol. 2014;24:308-23.

51. Quiralte J, Blanco C, Delgado J, Ortega N, Alcntára M, Castillo R, et al. Challenge-based clinical patterns of 223 Spanish patients with nonsteroidal anti-inflammatory-drug-induced-reactions. J Investig Allergol Clin Immunol. 2007;17:182-8.

52. Kidon M, Blanca-Lopez N, Gomes E, Terreehorst I, Tanno L, Ponvert $\mathrm{C}$, et al. EAACI/ENDA Position Paper: Diagnosis and management of hypersensitivity reactions to non- steroidal anti-inflammatory drugs (NSAIDs) in children and adolescents. Pediatr Allergy Immunol. 2018;29:469-80.
53. Mertes PM, Laxenaire MC. Allergy and anaphylaxis in anaesthesia. Minerva Anestesiol. 2004;70:285-91.

54. Hsu Blatman KS, Hepner DL. Current knowledge and management of hypersensitivity to perioperative drugs and radiocontrast media. $J$ Allergy Clin Immunol Pract. 2017;5:587-92.

55. Spoerl D, Nigolian H, Czarnetzki C, Harr T. Reclassifying anaphylaxis to neuromuscular blocking agents based on the presumed pathomechanism: IgE-mediated, pharmacological adverse reaction or "innate hypersensitivity"? Int J Mol Sci. 2017;18:1223.

56. Dong SW, Mertes PM, Petitipain N, Hasdenteufel F, Malinovsky JM Hypersensitivity reactions during anesthesia. Results from the ninth French survey (2005-2007). Minerva Anestesiol. 2012;78:868-78.

57. Mertes PM, Aimone-Gastin I, Guéant-Rodriguez RM, MoutonFaivre C, Audibert G, O'Brien J, et al. Hypersensitivity reactions to neuromuscular blocking agents. Curr Pharm Des. 2008;14:2809-25.

58. Brockow K, Romano A, Aberer W, Bircher AJ, Barbaud A, Bonadonna P et al. Skin testing in patients with hypersensitivity reactions to iodinated contrast media - a European multicenter study. Allergy. 2009;64:23441.

59. Brockow K. Contrast media hypersensitivit -scope of the problem. Toxicology. 2005;209:189-92.

60. Kvedariene V, Martins P, Rouanet L, Demoly P. Diagnosis of iodinated contrast media hypersensitivity: results of a 6-year period. Clin Exp Allergy. 2006; 36:1072-7.

61. Laroche D, Dewachter $\mathrm{P}$, Mouton-Faivre $\mathrm{C}$, Clément O. Immediate reactions following ICM injection: results of a 3-year prospective multicenter survey. Contrast Med Mol Imaging. 2006;1:81.

62. Gomez E, Ariza A, Blanca-Lopez N, Torres MJ. Non-immmediate hypersensitivity reactions to contrast media. Curr Opinion Allergy Clin Immunol. 2013;1345-53.

63. Pichler JW. Adverse side-effects to biological agents. Allergy 2006;61:912-20.

64. Isabwe G, Sanchez L, Castells M Management of adverse reactions to biologic agentes. Allergy Asthma Proc. 2017;38:409-18.

65. Wickner PG, Hong D. Immediate drug hypersensitivity. Curr Allergy Asthma Rep. 2016;16:49.

66. Castells M. Rapid drug desensitization for hypersensitivity reactions to chemotherapy and monoclonal antibodies in the 21st century. J Investig Allergol Clin Immunol. 2014;24:72-9.

67. Pagani M. The complex clinical picture of presumably allergic side effects to cytostatic drugs: symptoms, pathomechanism, reexposure and desensitization. Med Clin N Am. 2010;94:835-52.

68. Giavina-Bianchi P, Patil SU, Banerji A. Immediate hypersensitivity reaction to chemotherapeutic agents. J Allergy Clin Immunol Pract. 2017;5:593-9.

69. Limsuwan $\mathrm{T}$, Castells MC. Outcomes and safety of rapid desensitization for chemotherapy hypersensitivity. Expert Opin Drug Saf. 2010;9:39-53.

70. Castells M. Hypersensitivity to antineoplastic agents. Curr Pharm Des. 2008; 14:2892-901.

71. Aroldi F, Prochilo T, Bertocchi P, Zaniboni A. Oxaliplatininduced hypersensitivity reaction: underlying mechanisms and management. J Chemother. 2015;27:63-6.

72. Picard M. Management of hypersensitivity reactions to taxanes Immunol Allergy Clin North Am. 2017;37:679-93.

73. Cernadas JR, Brockow K, Romano A, Aberer W, Torres MJ, Bircher $A$, et al. General considerations on rapid desensitization for drug hypersensitivity - a consensus statement. Allergy. 2010;65:1357-66.

74. Scherer K, Brockow K, Aberer W, Gooi JH, Demoly P, Romano A, et al Desensitization in delayed drug hypersensitivity reactions - an EAACl position paper of the Drug Allergy Interest Group. Allergy. 2013;68:84452. 